\title{
Redesain Sistem Akuntansi Penerimaan Kas Pada Usaha Kecil Menengah Tahu Takwa Dung Tak Tong
}

\author{
Binti Fatimatuz Zahrok $^{1^{*}}$, Dianita Meirini ${ }^{2}$ \\ UIN Sayyid Ali Rahmatullah Tulungagung ${ }^{1,2}$ \\ bintifatima10@gmail.com, dmeirini@gmail.com
}

*Penulis Korespondensi

Diajukan : 1 Desember 2021

Disetujui : 22 Desember 2021

Dipublikasi : 1 Januari 2022

\begin{abstract}
In the operation of small and medium businesses, Tahu Takwa Dung Tak Tong is inseparable from cash inflow transactions. In the operation, obstacles were found in the form of a difference between physical cash and cash in the cash register. In addition, the task of recording cash with cash holders is controlled by the same person. This can weaken internal control. The purpose of this research is to design an improvement in the cash receipts accounting system especially the recording of cash receipts and to find out how to apply the cash receipts accounting designed system in the Tahu Takwa Dung Tak Tong small and medium enterprises and to find out how to apply the cash receipts accounting system design to the Tahu Takwa Dung Tak Tong small and medium enterprises. The used research approach is qualitative research methods. The result of this study are finding error points and multiple functions in the implemented system. The results of this study are found error points and found multiple functions in the system that has been implemented. The conclusion of the research is the improvement of the cash receipts accounting system and the separation of functions in the cash receipts system. With the improvement of the system as proposed, it aims to strengthen the internal control and is also useful in terms of saving the assets of these small and medium enterprises.
\end{abstract}

Keyword: accounting system, cash, cash receipts accounting system

\section{PENDAHULUAN}

Berkembangnya usaha kecil menengah memang sangat pesat pada sekarang ini, bahkan telah banyak berkonstribusi pada masyarakat Indonesia berupa penyediaan lapangan pekerjaan serta sumber pendapatan. Agar usaha kecil menengah ini tidak tumbuh pesat saja, tetapi juga berkualitas dan dapat bersaing dengan produk-produk lain, maka diperlukan pemberdayaan dan pengembangan yang berkelanjutan. Potensi besar akan dapat timbul akibat dari pemberdayaan juga pengembangan yang berkelanjutan, yang menyebabkan bergeraknya perekonomian masyarakat dan bertambahnya sumber pendapatan bagi banyak kalangan masyarakat dalam meningkatkan kesejahteraan kehidupannya. Di berbagai Negara berkembang di dunia, salah satu usaha yang memiliki peran dalam mengatasi masalah adalah usaha kecil menengah. Yang dimaksud masalah dalam hal ini yaitu masalah yang timbul berkaitan dengan hal ekonomi, sosial, dan lainnya misalnya dapat meminimalisir pengangguran, mengurangi angka kemiskinan dan juga meratakan pendapatan masyarakat banyak. 
Owner: Riset \& Jurnal Akuntansi

e -ISSN : 2548-9224 | p-ISSN : 2548-7507

Volume 6Nomor 1, Januari 2022

Disisi lain dalam suatu usaha kecil menengah terutama dalam bidang perdagangan, masih dihadapkan dengan permasalahan yang terletak pada proses pengajuan kredit ke bank. Menurut hasil wawancara dengan Bapak Bahrudin selaku pemilik usaha kecil menengah mengatakan, bahwa dalam pengajuan kredit ke bank persyaratannya yaitu fotokopi KTP, fotokopi KK, jaminan berupa BPKB/sertifikat, surat usaha dari desa, fotokopi surat nikah dan menyerahkan laporan pembukuan keuangan. Dengan persyaratan-persyaratan tersebut berguna untuk meyakinkan pihak bank agar mau memberikan kredit atau pinjaman dengan begitu pihak bank berkemungkinan tidak akan mendapatkan risiko yang tinggi dalam pemberian pinjaman.

Tahu Takwa Dung Tak Tong merupakan usaha kecil menengah milik Bapak Bahruddin yang terletak di Besi, RT.03, RW.03, Mlati, Mojo, Kediri. Usaha kecil menengah ini memproduksi tahu kuning luar dalam khas Kota Kediri, berbahan dasar kedelai pilihan. Ditambahkan beberapa bumbu dan rempah-rempah seperti cuka, kunyit dan garam. Yang kemudian diproses hingga menjadi tahu takwa. Produk tahu yang dihasilkan ini memiliki rasa gurih tanpa adanya penyedap rasa.

Dalam operasional usaha kecil menengah Tahu Takwa Dung Tak Tong ini tidak terlepas dari transaksi kas masuk. Dalam operasional tersebut ditemukannya kendala berupa adanya selisih antara kas fisik dengan kas di pencatatan kas. Hal tersebut sesuai dengan hasil wawancara dengan pemilik usaha. Menurut hasil wawancara dari Bapak Bahrudin selaku pemilik usaha, bahwa proses pencatatan keuangan saat ada uang masuk dan uang keluar, dicatat secara manual di buku oleh pemilik sendiri. Dan terakhir kali terdapat selisih jumlah uang antara total yang dicatatan dengan kas fisik. Lebih banyak yang ada di catatan dari pada kas fisik. Di samping itu tugas pencatatan kas dengan pemegang kas dikendalikan oleh orang yang sama. Hal tersebut dapat melemahkan pengendalian internal.

Dari penjabaran di atas timbul pertanyaan yaitu bagaimana sistem akuntansi penerimaan kas yang diperlukan dalam menjalankan suatu usaha? Dan bagaimana penerapan rancangan sistem akuntansi penerimaan kas dalam usaha tersebut? Dengan berbagai permasalahan yang timbul tersebut, menambah semangat peneliti dalam melaksanakan penelitian terkait perancangan sistem akuntansi penerimaan kas. Karena sejauh ini belum pernah ada yang melakukan penelitian pada usaha kecil menengah tersebut yang berkaitan dengan sistem akuntansi yang diterapkan disana.

Berdasarkan realita yang ada dipaparkan sebelumnya, tujuan dilakukannya penelitian ini yaitu: merancang perbaikan sistem akuntansi penerimaan kas terutama bagian pencatatan penerimaan kas pada usaha kecil menengah Tahu Takwa Dung Tak Tong dan mengetahui cara untuk menerapkan rancangan sistem akuntansi penerimaan kas pada usaha kecil menengah Tahu Takwa Dung Tak Tong.

Berikut terdapat beberapa penelitian serupa dengan penelitian ini, yang pertama memperoleh hasil berupa informasi terkait sistem informasi akuntansi yang diterapkan pada Batik Pramanca yang kemudian dari informasi tersebut dibuatlah perancangan sistem informasi akuntansi penerimaan kas berbasis web dengan metode RAD (Arum \& Nugroho, 2017).Yang kedua memperoleh hasil yaitu dalam pencatatan keuangan terkait penjualan dan penerimaan kas pada instansi yang diteliti masih menggunakan cara manual, dari hal tersebut peneliti akhirnya membuat rancang bangun sistem berbasis multiuser agar menghasilkan suatu laporan yang tepat, akurat juga efisien (Rubhiyanti \& Putri Pertiwi, 2020). Yang ketiga memperoleh hasil yaitu dari hasil analisa sistem informasi akuntansi penerimaan dan pengeluaran kas pada RSUP Dr. Kariadi Semarang, sistem yang diterapkan sudah memadai dan berfungsi secara efektif dalam pengendalian internal (Saifudin \& Pri, 2017). 
Owner: Riset \& Jurnal Akuntansi

e -ISSN : 2548-9224 | p-ISSN : 2548-7507

Volume 6Nomor 1, Januari 2022

DOI : https://doi.org/10.33395/owner.v6i1.578

\section{Sistem Akuntansi}

\section{STUDI LITERATUR}

Sistem adalah dua orang atau lebih dimana mereka bekerja sama, diikat pada ketentuan yang mengatur dan bersama-sama mencapai tujuan yang telah ditentukan. Sedangkan akuntansi adalah sebuah seni dalam mencatat, menggolongkan, mengikhtisarkan dan melaporkan suatu transaksi yang terjadi dengan cara yang sistematis serta dengan memenuhi standar yang berlaku(Kristeria et al., 2020).

Sistem akuntansi merupakan penyedia suatu informasi mengenai keuangan yang biasa digunakan oleh pihak manajemen dalam pengelolaan perusahaan seperti hal nya pengambilan keputusan. Sebelum menjadi suatu informasi yang berguna, sistem akuntansi ini berupa organisasi dari formulir atau dokumen, catatan-catatan, dan laporan-laporan yang kemudian diolah menjadi data bermanfaat (Mulyadi, 2018:3).Sistem akuntansi diartikan sebagai seperangkat metode, prosedur, dan pengendalian internal akuntansi yang dapat dilakukan secara manual maupun terkomputerisasi. Berguna untuk mengumpulkan, mencatat, mengklasifikasikan, menganalisis, mengikhtisarkan dan menyajikan informasi keuangan pada suatu perusahaan atau badan usaha dengan akurat dan tepat waktu. Hasilnya dapat digunakan oleh pihak manajemen dalam pengambilan keputusan (Zamzami et al., 2021:3).

Sistem akuntansi ini mengarah pada pengendalian internal pada suatu perusahaan. Dengan menjalankan kebijakan dan prosedur yang sesuai dengan pengendalian internal perusahaan menjaga keakuratan informasi yang dihasilkan dan memastikan sistem berjalan dengan baik (Zahro, 2019). Yang termasuk ke dalam unsur dari sistem akuntansi secara pokok yaitu formulir atau dokumen, jurnal, buku besar, buku pembantu dan laporan (Mulyadi, 2018:3). Pengembangan sistem akuntansi bertujuan sebagai penyedia informasi dalam mengelola kegiatan usaha yang baru dirintis, sebagai bahan perbaikan informasi yang timbul dari sistem sebelumnya, sebagai bahan dalam pengendalian dan pengecekan akuntansi dan internal (Mulyadi, 2018:15).

\section{Kas}

Kas memiliki peran penting dalam perusahaan, yang apabila posisinya terganggu akan menimbulkan dampak buruk bagi perusahaan. Kas memiliki sifat mudah dipindahtangankan dan tidak dapat dibuktikan pemiliknya, maka uang kas yang keluar akan mudah disalahgunakan (Andayani \& Aprilia, 2020). Oleh sebab itu kas sering disebut memiliki sifat yang liquid (cair) dalam perusahaan (Wayan Esteria et al., 2016).Yang termasuk ke dalam kas adalah seluruh alat-alat pembayaran atau instrument berupa uang tunai yang digunakan dan diterima secara umum, digunakan baik perorangan, dalam perusahaan atau disimpan di bank (IAI, 2009).

Kas memiliki peran penting dalam setiap laporan yang berkaitan dengan keuangan dan berfungsi sebagai bagian dari sistem akunatansi. Dalam berbagai transaksi akun yang paling banyak terlibat yaitu kas. Dalam transaksi di perusahaan memerlukan kas sebagai media tukar. Kas memberikan dasar pengukuran dan akuntansi serta tidak dengan secara langsung ikut terlibat dalam transaksi yang terjadi pada pos-pos lainnya (James, 2009:239).

Penerimaan kas dan pengeluaran kas akan terus terjadi secara terus menerus dalam kondisi perusahaan beroperasi. Kas akan mengalami fluktuasi apabila dalam perusahaan terjadi kelebihan aliran kas baik yang masuk atau keluar dan masih bertahan di perusahaan. Hal ini akan menimbulkan perubahan antar waktu ke waktu dalam suatu perusahaan. 
Owner: Riset \& Jurnal Akuntansi

e -ISSN : 2548-9224 | p-ISSN : 2548-7507

Volume 6Nomor 1, Januari 2022

\section{Sistem Akuntansi Penerimaan Kas Tunai}

Sistem akuntansi penerimaan kas merupakan satu jaringan prosedur yang dibuat oleh perusahaan berguna untuk pelaksanaan transaksi penerimaan uang atau kas yang bersumber dari proses penjualan (Arianita et al., 2016). Sistem ini dibuat berdasar ketentuan yang diterapkan pada perusahaan dengan menggunakan pola terpadu. Sistem akuntansi penerimaan kas merupakan sistem yang dibuat untuk kepentingan dalam perusahaan, sistem ini berfungsi menangani transaksi-transaksi penerimaan kas tunai dan penerimaan kas dari piutang yang terjadi(Fathoni, 2018).

Sumber penerimaan kas terbesar di perusahaan berasal dari transaksi penjualan tunai. Transaksi penjualan tunai ini ada tiga macam yaitu over-the-counter sale, cash-on-delivery sale, dan dari credit card sale (Pradnyawati et al., 2019). Cara pelaksanaan penjualan tunai di perusahaan yaitu pembeli harus melaksanakan pembayaran dahulu, kemudian barang yang dibeli akan diserahkan oleh penjual. Setelah transaksi terselesaikan, dilanjutkan dengan perusahaan mencatat transaksi penjualan tersebut (Mulyadi, 2018:380).

Dalam sistem penerimaan kas dari penjualan tunai fungsi yang terkait adalah (Mulyadi, 2018): fungsi penjualan, kas, gudang, pengiriman, dan akuntansi. Dokumendokumen dari penjualan tunai yang digunakan dalam sistem akuntansi penerimaan kas yaitu(Mulyadi, 2018:386): faktur penjualan tunai, pita register kas (cash register tape), credit cars sales slip, bill of lading, faktur penjualan COD, bukti setor bank, dan rekapitulasi beban pokok penjualan. Catatan akuntansi yang digunakan dalam sistem penerimaan kas dari penjualan tunai adalah (Mulyadi, 2018:385): jurnal penjualan, jurnal penerimaan kas, jurnal umum, kartu persediaan, dan kartu gudang.

\section{METODE}

Pendekatan dalam penelitian ini yang digunakan adalah menggunakan metode penelitian kualitatif dimana metode ini berlandaskan filsafat enterpretif atau postpositivisme(Sugiyono, 2018:9). Lebih tepatnya jenis penelitian ini adalah kualitatif studi kasus, peneliti pada hal ini meneliti obyek dengan waktu tertentu sehingga hasil penelitian ini tidak luas melainkan terbatas pada obyek yang telah ditentukan peneliti(Yudowati, 2018).

Berikut merupakan diagram terkait metode penelitian yang digunakan dalam penelitian ini:

Gambar 1. Diagram Metode Penelitian

\begin{tabular}{|c|c|}
\hline $\begin{array}{l}\text { Permasalahan: } \\
\text { - Adanya selisith antan kas fisik dengan } \\
\text { kas di pencatatan kas } \\
\text { Terjadi perangkapan tagas }\end{array}$ & 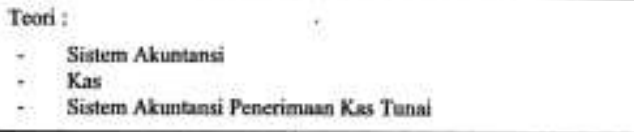 \\
\hline $\begin{array}{l}\text { Hasil: } \\
\text { Setelah dianaliais secara keselunuhan, delam } \\
\text { penefitian akhirnya diambil judul yaitu } \\
\text { Rodesain Sistem Akuntansi Penerimaan Kas } \\
\text { paila Usaha Kecil Menengah Tahu Takwa } \\
\text { Dung Tak Tong. Yaitu dengas mengusulkan } \\
\text { perbaruan sistcen dengan disesuaikan } \\
\text { kebueuhan pada usaha tersebut. }\end{array}$ & 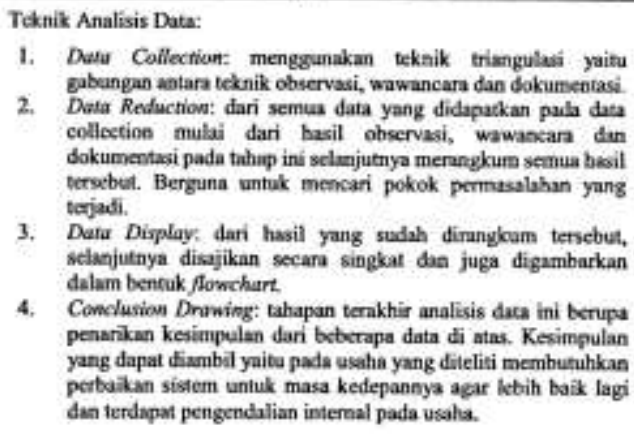 \\
\hline
\end{tabular}


Owner: Riset \& Jurnal Akuntansi

e-ISSN : 2548-9224 |p-ISSN : 2548-7507

Volume 6Nomor 1, Januari 2022

Usaha Kecil Menengah Tahu Takwa Dung Tak Tong merupakan usaha yang menjalankan produksi dan penjualan tahu takwa khas Kota Kediri. Prosedur yang diterapkan pada usaha ini adalah prosedur penerimaan kas secara tunai. Sumber penerimaan kas disini dari hasil penjualan tahu takwa. Banyaknya tahu yang diproduksi sendiri tidak selalu banyak, tergantung pada jumlah pesanan dan juga sebagai persediaan untuk di outlet-outlet.

Dalam sebuah usaha pasti ada yang namanya struktur organisasi, pada usaha kecil menengah ini pun juga terdapat struktur organisasi yang diterapkan, yaitu terdiri dari pemilik usaha yang membawahi karyawan bagian produksi dan karyawan bagian pemasaran. Tujuan diadakannya struktur organisasi pada usaha ini yaitu untuk menguraikan wewenang dan tanggungjawab setiap fungsi organisasi pada usaha kecil menengah ini.

Usaha Kecil Menengah Tahu Takwa Dung Tak Tong didirikan oleh Bapak Bahruddin pada tahun 2015. Dalam struktur organisasi yang berlaku di usaha ini, Bapak Bahruddin dibantu oleh fungsi produksi dan fungsi pemasaran. Fungsi produksi dilaksanakan oleh pemilik usaha dengan dibantu empat orang karyawan yaitu Sa'i, Kemis, Fauzi, dan Najib. Fungsi ini bertugas untuk melaksanakan kegiatan produksi tahu takwa, pengemasan tahu takwa, dan bertanggungjawab terhadap persediaan tahu takwa serta menyiapkan barang pesanan. Fungsi pemasaran dilaksanakan oleh pemilik usaha dengan dibantu tiga orang karyawan yaitu Devadra, Sepvia, Pinanga. Fungsi ini bertugas memasarkan barang dagang baik melalui outlet maupun secara online dengan media sosial berupa Instagram, whatsapp dan facebook. Selain itu fungsi ini juga bertugas menerima order dan mengirimkan barang dagang kepada pembeli.

Sedangkan pencatatan penerimaan kas pada usaha ini dilaksanakan sendiri oleh pemilik usaha. Pencatatan keuangan yang diterapkan di Usaha Kecil Menengah ini yaitu dengan cara yang sederhana, yaitu dengan mengurangkan pendapatan dengan pengeluaran menghasilkan laba usaha.

Proses pencatatan yang dilakukan yaitu dimulai dari nota yang ada atau bukti transaksi yang ada dimasukkan ke dalam buku kas harian. Buku kas harian disini isinya yaitu tabel pendapatan, pengurangan dan total laba.

Tabel 1. Flowchart Prosedur Penerimaan Kas dari Penjualan Usaha Kecil Menengah Tahu Takwa Dung Tak Tong

\begin{tabular}{|c|c|c|c|}
\hline Produksi & Pemasaran & Pembeli & $\begin{array}{c}\text { Pemilik } \\
\text { Usaha }\end{array}$ \\
\hline
\end{tabular}


Owner: Riset \& Jurnal Akuntansi

e-ISSN : 2548-9224 |p-ISSN : 2548-7507

Volume 6Nomor 1, Januari 2022

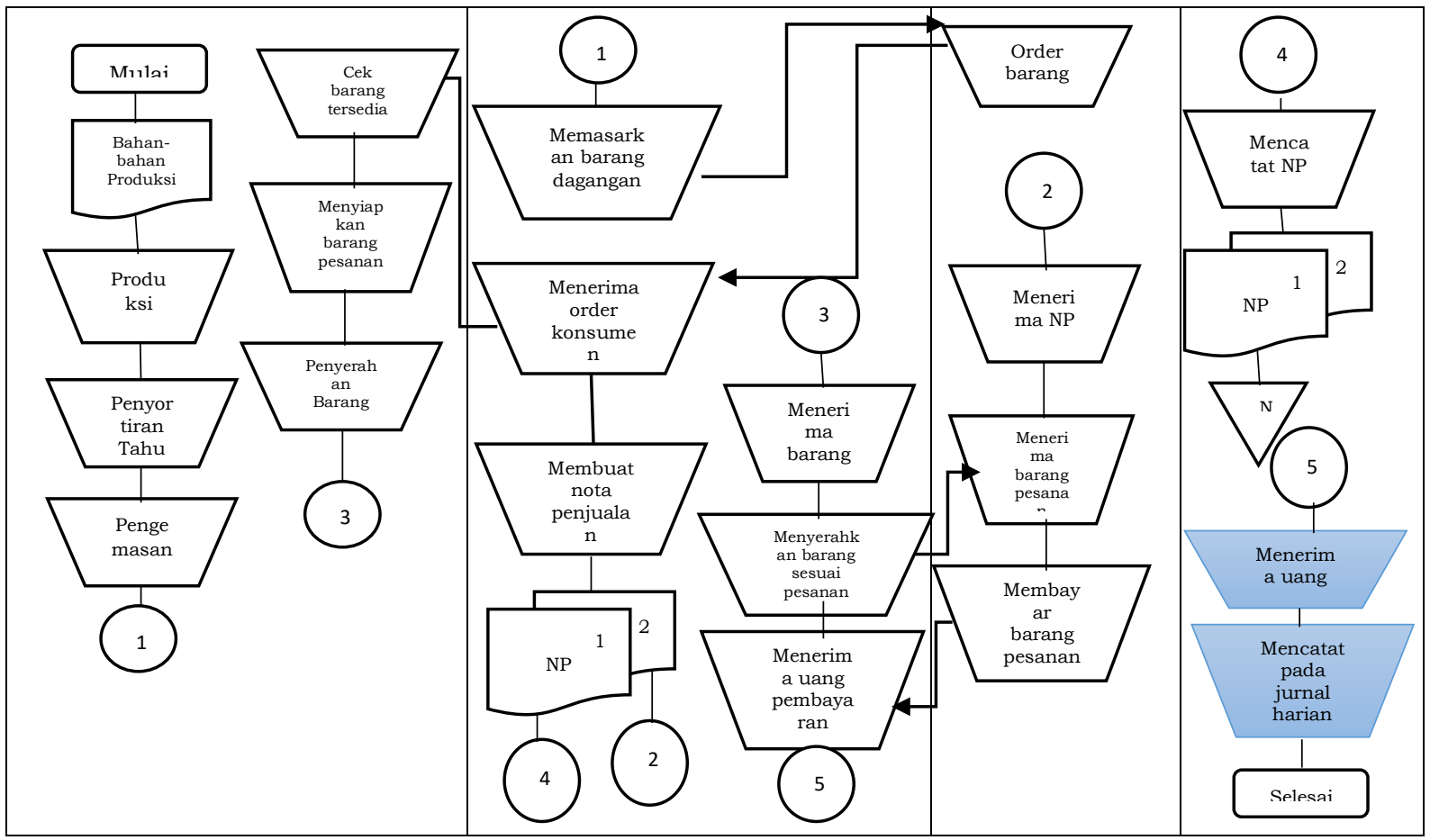

Sumber: hasil wawancara dengan Bapak Bahrudin selaku pemilik usaha.

\section{Evaluasi Sistem Akuntansi Penerimaan Kas Usaha Kecil Menengah Tahu Takwa Dung Tak Tong}

Sebelum membuat suatu perancangan sistem, sebelumnya akan mengidentifikasi permasalahan yang ada di dalam badan usaha tersebut. Berdasarkan permasalahan sudah dijelaskan pada bagian pendahuluan dapat disimpulkan yaitu: adanya selisih antara kas fisik dengan kas di pencatatan, dan tugas pencatatan kas dengan pemegang kas dikendalikan oleh orang yang sama atau dapat dikatakan terjadi perangkapan tugas dalam pelaksanaan struktur organisasinya.

Adanya selisih antara kas fisik dengan kas di pencatatan ini, dapat dilihat dari titik error sistem yang sebelumnya diterapkan pada badan usaha. Seperti pada flowchart prosedur sistem penerimaan kas yang ada di atas terutama pada bagian yang warnanya berbeda. Selain itu dalam struktur organisasi yang sudah diterapkan pada usaha kecil menengah ini terjadi perangkapan wewenang dan tanggung jawab terhadap fungsi-fungsi yang ada. Seperti hal nya yang terjadi pada bagian produksi yang menjalankan dua fungsi yaitu fungsi produksi dan fungsi gudang. Sedang bagian pemasaran yang di dalamnya bertugas menjalankan dua fungsi yaitu penjualan dan pengiriman. Dan pemilik usaha menjalankan fungsi sebagai fungsi akuntansi yang mencatat keuangan dalam usaha ini. Hal ini seperti yang dipaparkan oleh salah satu karyawan produksi:

"pembagian karyawan disini hanya ada dua bagian, yaitu bagian produksi dan bagian pemasaran mbak. Bagian produksi itu yang menjalankan proses produksi, pengemasan dan menyiapkan barang untuk dikirim. Bagian pemasaran yang menjalankan tugas menerima orderan dan mengirimkan barang ke pembeli. Sedangkan yang mencatat uang masuk uang keluar itu bapak sendiri, mbak" kata Mas Devandra.

Selain evaluasi pada beberapa permasalahan sebelumnya, yang perlu dievaluasi pada usaha ini yaitu sumberdaya manusia yang bekerja pada usaha ini. Sumberdaya manusia di sini 
Owner: Riset \& Jurnal Akuntansi

e-ISSN : 2548-9224 | p-ISSN : 2548-7507

Volume 6Nomor 1, Januari 2022

memiliki peran yang sangat penting bagi keberlangsungan kegiatan usaha ini. Berdasarkan penjelasan struktur organisasi dan fungsi-fungsinya di atas dapat dilihat bahwa karyawankaryawan sudah menjalankan tugas-tugasnya dengan baik sesuai dengan apa yang ditugaskan. Walaupun terjadi perangkapan fungsi akan tetapi tetap berjalan lancar.

Dari beberapa permasalahan yang ada, apabila terus-menerus menjalankan sistem yang seperti sudah diterapkan pada badan usaha akan mengakibatkan kerugian bagi badan usaha. Terutama pada bagian pencatatan kas, yang juga merangkap sebagai pemegang kas. Di sini dapat menyebabkan lemahnya pengendalian internal pada badan usaha. Oleh sebab itu memerlukan perbaruan sistem yang dapat memperkuat pengendalian internal badan usaha.

\section{PEMBAHASAN}

\section{Perancangan Sistem Akuntansi Penerimaan Kas}

\section{Rancangan Prosedur Membentuk Sistem Akuntansi Penerimaan Kas}

Prosedur Produksi. Uraian penjelasan terkait prosedur ini yaitu fungsi produksi menyiapkan bahan-bahan untuk produksi tahu takwa, kemudian melakukan proses produksi tahu mulai perendaman hingga siap saji, menyortir tahu atau memilah tahu yang layak jual dengan yang tidak layak jual, tahu yang layak jual kemudian di kemas dengan masing-masing kemasan berisi 8 kotak tahu, kemudian dilakukan pencatatan pada kartu harga pokok produksi dan tahu yang sudah dikemas akan dipasarkan oleh fungsi penjualan. Kartu harga pokok produksi di sini dibuat rangkap dua, yang lembar kedua dijadikan arsip, sedangan lembar pertama diberikan kepada bagian akuntansi. Dibandingkan dengan prosedur sebelumnya, keunggulan diterapkannya prosedur produksi ini yaitu lebih efisien dalam pelaksanaan tugas. Karena pada prosedur produksi yang diusulkan ini fokusnya hanya dalam hal produksi, pengemasan dan pencatatan pada kartu harga pokok produksi saja, tidak mencakup bagian persediaan barang dan menyiapkan barang untuk pengiriman.

Prosedur Penjualan. Uraian penjelasan terkait prosedur ini yaitu fungsi penjualan menerima order dari pembeli dan menerima tahu yang sudah dikemas dari bagian produksi, mengisi faktur penjualan tunai yang kemudian diberikan kepada pembeli. Dilanjutkan pembeli melakukan proses pembayaran pada fungsi kas. Dan faktur yang lainnya diserahkan pada fungsi gudang dan fungsi pengiriman untuk proses penyiapan barang pesanan dan pengiriman barang pesanan pada pembeli. Dibandingkan dengan prosedur sebelumnya yaitu bagian pemasaran tidak adanya bagian penjualan, prosedur ini mempermudah dalam pengendalian internal yaitu pencatatan order dari pembeli dan pengisian faktur penjualan tunai lebih efisien, dan dibukukan dengan rinci tanpa perangkapan tugas.

Prosedur Penerimaan Kas. Uraian penjelasan terkait prosedur ini yaitu fungsi kas menerima pembayaran dari pembeli dan mengoperasikan pita register atau dapat berupa nota kontan. Serta memberikan cap "lunas" pada FPT yang berguna dalam pengambilan barang oleh pembeli pada fungsi pengiriman. Dibandingkan dengan prosedur sebelumnya yang terjadi perangkapan tugas, dan fungsi kas ini masih dikendalikan oleh pemilik, pada prosedur ini fungsi kas dipisahkan. Hal ini berguna untuk mencegah kekeliruan atau adanya selisih antara kas fisik dengan kas di catatan.

Prosedur Penyerahan Barang. Uraian penjelasan terkait prosedur ini yaitu fungsi pengiriman menyerahkan barang pesanan kepada pembeli. Keunggulan diadakannya prosedur ini yaitu agar fungsi pengiriman dipisahkan sendiri dan hanya fokus pada pengiriman saja. Tidak terjadi perangkapan fungsi dengan fungsi yang lainnya seperti yang sebelumnya diterapkan pada usaha kecil menengah ini. 
Owner: Riset \& Jurnal Akuntansi

e-ISSN : 2548-9224 | p-ISSN : 2548-7507

Volume 6Nomor 1, Januari 2022

Prosedur Pencatatan Penjualan Tunai. Uraian penjelasan terkait prosedur ini yaitu fungsi akuntansi mencatat transaksi-transaksi yang terjadi dalam buku pencatatan sesuai pembagiannya. Seperti penjualan tunai yang dicatat pada jurnal penjualan dan penerimaan kas. Selain itu fungsi akuntansi bertugas untuk mencatat persediaan barang baik berkurangnya maupun bertambahnya persediaan barang pada kartu persediaan. Keunggulan dari prosedur ini yaitu fungsi akuntansi dipisahkan dengan fungsi kas. Dengan begitu fungsi akuntansi ini fokus pada pencatatan transaksi pada jurnal penjualan tunai dan jurnal penerimaan kas serta mencatat persediaan.

Prosedur Penyetoran Kas ke Bank. Pada prosedur ini terdapat sistem pengendalian internal yang diterapkan pada kas, yaitu segera melakukan penyetoran semua kas yang diterima pada suatu hari ke bank. Dalam prosedur ini yang melakukan penyetoran kas ke bank adalah fungsi kas, kas yang disetorkan dalam jumlah penuh. Keunggulan prosedur penyetoran kas ke bank ini yaitu agar uang kas hasil penjualan ini dapat langsung masuk ke rekening bank, tidak dipegang oleh fungsi kas. Karena apabila kas masih dipegang oleh fungsi kas secara cash dapat memungkinkan kas hilang maupun kas dipakai untuk keperluan lain di luar usaha.

Prosedur Pencatatan Penerimaan Kas. Pada prosedur ini bukti setor kas ke bank yang diterima dari bank akan dicatat pada jurnal penerimaan oleh fungsi kas. Keunggulan dari adanya prosedur ini yaitu setiap transaksi penerimaan kas akan langsung dicatat oleh fungsi kas agar tidak terjadi selisih kas fisik dengan kas di pencatatan.

Prosedur Pencatatan Beban Pokok Penjualan. Uraian penjelasan terkait prosedur ini yaitu berdasarkan data yang telah dicatat dalam kartu persediaan akan dibuat rekapitulasi beban pokok penjualan oleh fungsi akuntansi. Setelah rekapitulasi beban pokok penjualan ini dibuat, hasilnya akan dipakai sebagai dasar pembuatan bukti memorial sebagai sumber dalam pencatatan beban pokok penjualan pada jurnal umum. Dengan dilaksanakannya prosedur pencatatan beban poko penjualan maka persediaan barang dagang berupa tahu ini akan lebih terkendali jumlahnya, karena selalu dicatat baik barang masuk maupun barang keluar.

Dari penjelasan terkait prosedur penerimaan kas yang diusulkan, dapat dilihat secara jelas yaitu dengan adanya pemisahan fungsi-fungsi seperti fungsi produksi, fungsi, penjualan, fungsi kas, fungsi gudang, fungsi pengiriman dan fungsi akuntansi maka sistem yang ada dalam usaha kecil menengah ini lebih terorganisir. Selain itu unsur pengendalian internal pada usaha kecil menengah juga terpenuhi. Dengan begitu tidak akan menimbulkan kerugian yang dapat membahayakan asset yang dimiliki badan usaha ini.

Tabel 2.1 Flowchart Sistem Penerimaan Kas yang diusulkan untuk Usaha Kecil Menengah

Tahu Takwa Dung Tak Tong

\begin{tabular}{|c|c|c|c|}
\hline Produksi & Penjualan & Kas & Gudang \\
\hline
\end{tabular}


Owner: Riset \& Jurnal Akuntansi

e-ISSN : 2548-9224 | p-ISSN : 2548-7507

Volume 6Nomor 1, Januari 2022

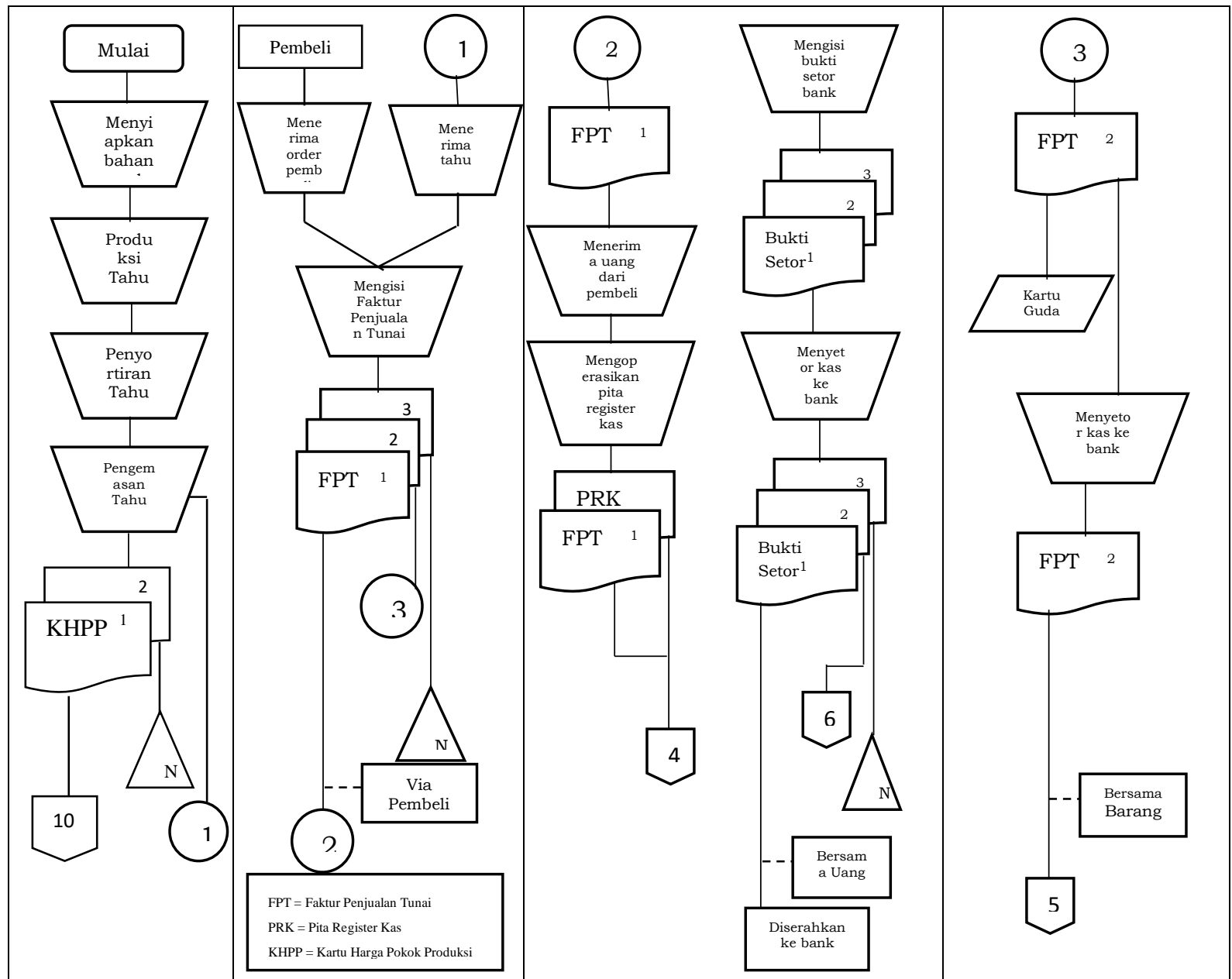

Tabel 2.2 Flowchart Sistem Penerimaan Kas yang diusulkan untuk Usaha Kecil Menengah Tahu Takwa Dung Tak Tong

\section{Pengiriman}

Akuntansi 


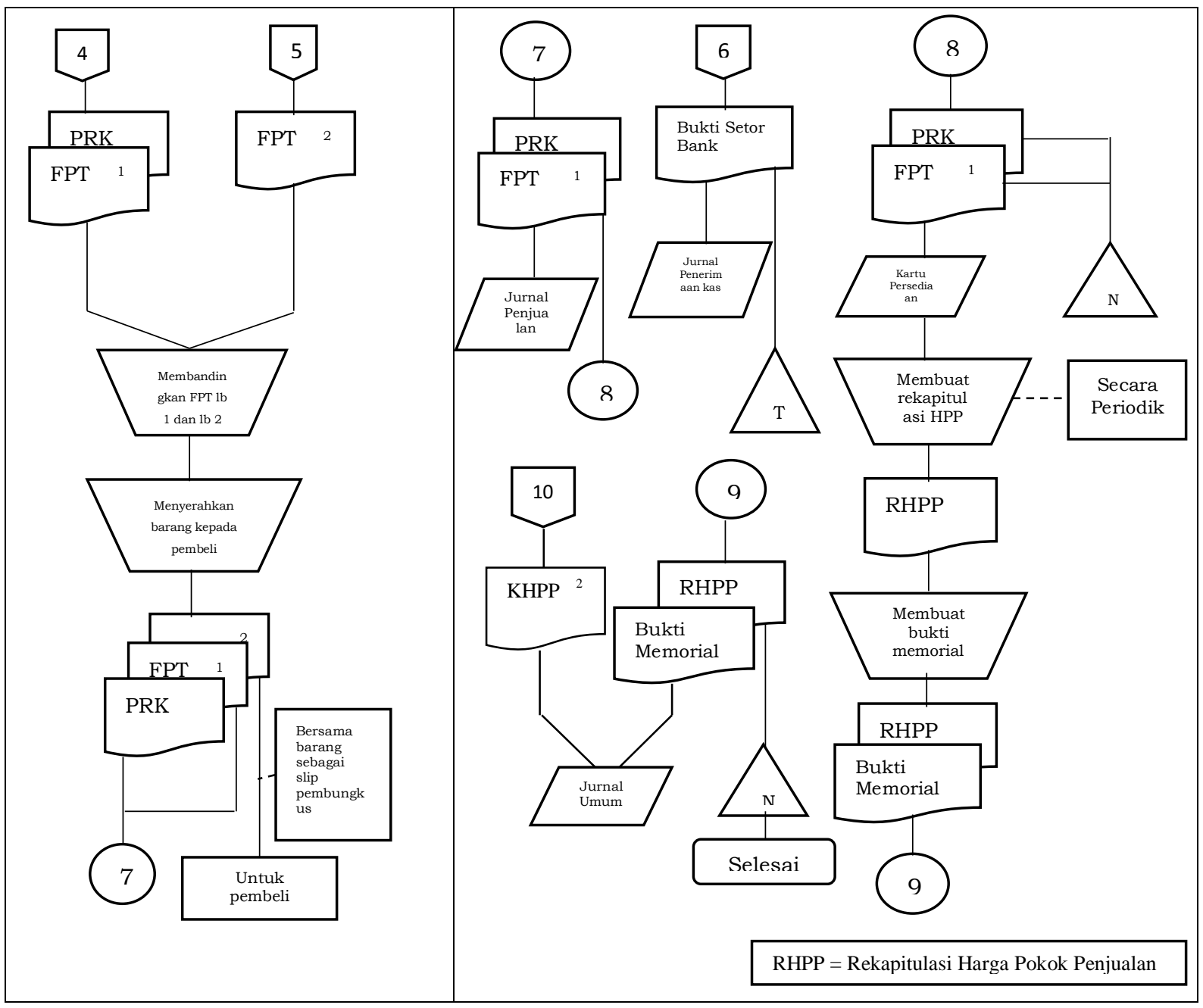

\section{Perancangan Struktur Organisasi dalam Usaha Kecil Menengah yang Diusulkan}

Dalam suatu badan usaha memerlukan struktur organisasi yang memadai berguna agar semua kegiatan di dalam badan usaha dapat berjalan dengan lancar sesuai dengan jobdisk dari masing-masing baik pemilik usaha maupun karyawan. Dengan adanya perancangan struktur organisasi yang baru ini akan membuat perusahaan dapat terkoordinasi, tertata dan terorganisasi dengan baik. Adanya struktur organisasi ini merupakan salah satu pengendalian internal yang harus diterapkan suatu badan usaha. Struktur organisasi dalam usaha kecil menengah yang diusulkan yaitu dipimpin oleh pemilik usaha dan membawahi karyawan dengan enam bagian. Yaitu bagian produksi, penjualan, kas, gudang, pengiriman, dan akuntansi.

\section{Hasil Penerapan Rancangan Sistem Akuntansi Penerimaan Kas yang Diusulkan}

Berdasarkan rancangan sistem akuntansi penerimaan kas yang telah diusulkan, maka dilakukan uji coba dalam penerapannya di usaha kecil menengah Tahu Takwa Dung Tak Tong ini. Uji coba ini dilakukan selama tiga hari pada jam kerja oleh pemilik usaha dan seorang karyawan terpilih bernama Pinanga yang tingkat pendidikannya lebih memadai dibandingkan karyawan lain.

Tabel 3. Perbandingan Sebelum Perbaruan dan Hasil Uji Coba Perbaruan Sistem

\begin{tabular}{|c|c|c|c|}
\hline Bagian & $\begin{array}{c}\text { Sebelum Adanya } \\
\text { Perbaruan Sistem }\end{array}$ & $\begin{array}{c}\text { Hasil Uji Coba Perbaruan } \\
\text { Sistem }\end{array}$ & Bukti-Bukti \\
\hline
\end{tabular}


Owner: Riset \& Jurnal Akuntansi

e-ISSN : 2548-9224 | p-ISSN : 2548-7507

Volume 6Nomor 1, Januari 2022

DOI : https://doi.org/10.33395/owner.v6i1.578

\begin{tabular}{|c|c|c|c|}
\hline Produksi & $\begin{array}{l}\text { Pada bagian produksi } \\
\text { juga menjalankan } \\
\text { tugas untuk cek barang } \\
\text { tersedia, menyiapkan } \\
\text { barang pesanan, dan } \\
\text { menyerahkan barang } \\
\text { pada bagian } \\
\text { pemasaran. }\end{array}$ & $\begin{array}{l}\text { Pada sistem yang sudah } \\
\text { diperbarui yang membedakan } \\
\text { bagian ini adalah kegiatannya, } \\
\text { yaitu berfokus hanya pada } \\
\text { proses produksi saja tidak } \\
\text { menjalankan fungsi lain. Dan } \\
\text { pada bagian ini dilakukan } \\
\text { pencatatan pada kartu harga } \\
\text { pokok produksi. }\end{array}$ & $\begin{array}{l}\equiv \\
\equiv\end{array}$ \\
\hline Penjualan & \begin{tabular}{lr}
\multicolumn{2}{l}{ Pada sistem bagian ini } \\
diberi nama yaitu \\
bagian pemasaran, \\
akan & tetapi \\
menjalankan & tugas \\
sebagai & bagian \\
penjualan. Selain itu \\
pada bagian ini juga \\
menjalankan fungsi \\
pengiriman \\
menyerahkan barang \\
pesanan & atau \\
menerima & uang \\
pembayaran & dari \\
pembeli. &
\end{tabular} & $\begin{array}{l}\text { Pada sistem yang } \\
\text { diperbarui ini } \\
\text { pemasaran berganti } \\
\text { bagian } \\
\text { menjadi bagian penjualan. } \\
\text { Yang membedakan dengan } \\
\text { sistem sebelumnya yaitu } \\
\text { perubahan nama dari NP (Nota } \\
\text { Penjualan) menjadi FPT } \\
\text { (Faktur Penjualan Tunai), dan } \\
\text { yang semula rangkap dua } \\
\text { menjadi rangkap } 3 \text { karena } \\
\text { lembar ketiga disini akan } \\
\text { diarsipkan. }\end{array}$ & $\begin{array}{l}=- \\
=- \\
=\end{array}$ \\
\hline Kas & - & $\begin{array}{l}\text { Bagian ini sebelumnya } \\
\text { menjadi satu dengan bagian } \\
\text { pemasaran, akan tetapi pada } \\
\text { sistem yang sudah diperbarui } \\
\text { ini diadakan bagian ini } \\
\text { disendirikan. Bagian ini } \\
\text { menjalankan fungsi menerima } \\
\text { uang dari pembeli, mencetak } \\
\text { pita register, dan menyetorkan } \\
\text { kas ke bank. }\end{array}$ & 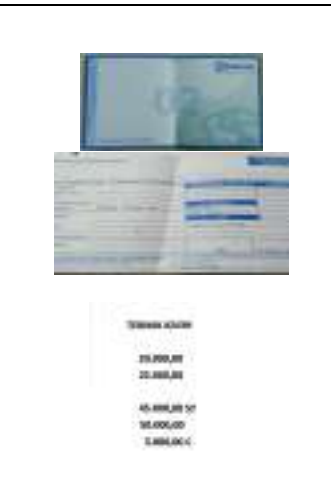 \\
\hline Gudang & - & $\begin{array}{l}\text { Bagian ini sebelumnya } \\
\text { dilaksanakan oleh bagian } \\
\text { produksi, akan tetapi pada } \\
\text { sistem yang telah diperbarui } \\
\text { bagian ini disendirikan. Bagian } \\
\text { ini bertugas untuk menyiapkan } \\
\text { barang pesanan dan mencatat } \\
\text { pada kartu gudang. }\end{array}$ & \\
\hline Pengiriman & - & $\begin{array}{l}\text { Bagian ini pada sistem yang } \\
\text { lama dijalankan oleh bagian } \\
\text { pemasaran. Pada sistem yang } \\
\text { sudah diperbarui ini }\end{array}$ & $\frac{E_{-1}-}{-}$ \\
\hline
\end{tabular}


Owner: Riset \& Jurnal Akuntansi

e-ISSN : 2548-9224 |p-ISSN : 2548-7507

Volume 6Nomor 1, Januari 2022

DOI : https://doi.org/10.33395/owner.v6i1.578

\begin{tabular}{|c|c|c|c|}
\hline & & $\begin{array}{lrr}\text { disendirikan } & \text { menjadi } & \text { bagian } \\
\text { pengiriman, yang berfokus } \\
\text { pada pengiriman } & \text { atau } \\
\text { penyerahan barang } & \text { kepada } \\
\text { pembeli saja. } & \\
\end{array}$ & \\
\hline Akuntansi & $\begin{array}{lr}\text { Bagian ini pada sistem } \\
\text { lama dijalankan oleh } \\
\text { pemilik usaha } & \text { sendiri, } \\
\text { akan tetapi } & \text { hanya } \\
\text { mencatat } & \text { nota } \\
\text { penjualan, menerima } \\
\text { uang dari bagian } \\
\text { pemasaran r dan } \\
\text { mencatat jurnal harian } \\
\text { saja. }\end{array}$ & $\begin{array}{l}\text { Pada sistem yang sudah } \\
\text { diperbarui, bagian akuntansi } \\
\text { diadakan sendiri, bukan lagi } \\
\text { dari pemilik usaha yang } \\
\text { menjalankan. } \\
\text { menjalankan fungsi untuk } \\
\text { mencatat FPT dan PRK pada } \\
\text { jurnal penjualan, mencatat } \\
\text { bukti setor bank pada jurnal } \\
\text { penerimaan kas, mencatat FPT } \\
\text { dan PRK pada kartu } \\
\text { persediaan, membuat } \\
\text { rekapitulasi harga pokok } \\
\text { penjualan dan membuat bukti } \\
\text { memorial, kemudian mencatat } \\
\text { RHPP, bukti memorial dan } \\
\text { KHPP pada jurnal umum. }\end{array}$ & 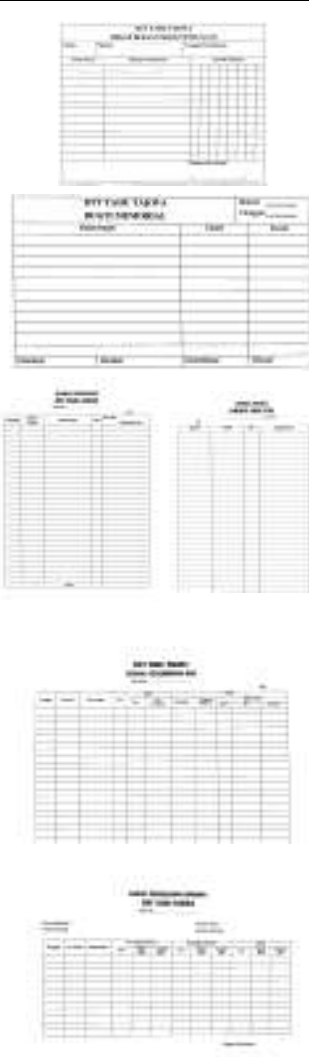 \\
\hline
\end{tabular}

Setelah pengujian sistem dilakukan, ditemukan beberapa hasil sesuai dengan harapan. Pihak usaha kecil menengah ini merasa terbantu dengan adanya sistem pencatatan yang terperinci ini mulai dari bukti transaksi hingga laporan keuangan, akan tetapi masih memerlukan beberapa waktu lagi untuk mempelajari dan memahami sistem ini. Selain itu ditemukan beberapa kelemahan dalam penerapan pencatatan berbasis manual ini, yaitu berkemungkinan buku catatan hilang dan rusak. Dalam melakukan pencatatan sendiri harus dilakukan dengan teliti agar tidak terdapat kesalahan dalam menuliskan data keuangan.

"Pencatatan akuntansi seperti ini memang sangat membantu dalam usaha ini, tapi saya masih memerlukan beberapa waktu untuk terus mempelajari dan memahami prosesnya bagaimana. Karena saya dulu bukan dari jurusan IPS yang sudah pernah diajarkan materi akuntansi, dan jika melakukan pencatatan tidak teliti pasti akan berdampak pada lainnya" kata Mbak Pinanga.

Dalam penerapan sistem akuntansi penerimaan kas yang diusulkan pada usaha ini, diperlukan sumberdaya manusia yang mumpuni berguna sebagai pelaku dalam menjalankan sistem. Dengan adanya karyawan yang terbatas, maka memerlukan pembagian ulang penempatan karyawan sesuai dengan struktur organisasi yang diusulkan. Dan penerapan ini tidaklah mudah dengan karyawan yang terbatas dan memerlukan waktu juga untuk adaptasi.

"Sebenarnya sistem yang diusulkan ini bagus dan sudah sesuai jika diterapkan, tapi saya belum bisa sepenuhnya menerapkannya terutama bagian struktur organisasi. Karena disini saya hanya mempunyai tujuh orang karyawan saja, sedang jika 
Owner: Riset \& Jurnal Akuntansi

e-ISSN : 2548-9224 | p-ISSN : 2548-7507

Volume 6Nomor 1, Januari 2022

DOI : https://doi.org/10.33395/owner.v6i1.578

menerapkan struktur organisasi yang sesuai membutuhkan tambahan karyawan. Mungkin yang bisa diterapkan terlebih dahulu yang bagian pencatatan kasnya, walaupun perlu belajar lagi” kata Bapak Bahrudin selaku pemilik usaha.

\section{KESIMPULAN}

Dari hasil penelitian pada usaha kecil menengah Tahu Takwa Dung Tak Tong, dapat ditarik kesimpulan yaitu perbaikan sistem akuntansi penerimaan kas dan pemisahan fungsi dalam sistem penerimaan kas. Hal ini disebabkan sistem yang sebelumnya diterapkan pada usaha ini mengalami error sistem dan mengakibatkan terjadinya masalah berupa adanya selisih antara kas fisik dengan kas di pencatatan dan terdapat perangkapan tugas seperti hal nya pemegang kas dengan pencatat kas yang dikendalikan oleh orang yang sama. Dengan adanya perbaikan sistem seperti yang telah diusulkan bertujuan untuk memperkuat pengendalian internal pada usaha kecil menengah ini dan juga berguna dalam hal menyelamatkan aset-aset yang dimiliki usaha kecil menengah ini. Dalam uji coba penerapan sistem ditemukan hasil yang sesuai dengan harapan pemilik usaha. Respon pemilik usaha terhadap sistem yang diusulkan juga baik, dan yang akan mulai diterapkan yaitu bagian pencatatan kas terlebih dahulu dikarenakan apabila menerapkan sistem organisasi sesuai prosedur yang diusulkan memerlukan sumberdaya manusia yang cukup banyak. Sedangan jumlah karyawan yang ada belum memadai.

\section{REFERENSI}

Andayani, T. D., \& Aprilia, E. (2020). Analisis Sistem Akuntansi Penerimaan dan Pengeluaran Kas pada CV Wijaya. Jurnal Neraca, 16(2), 103-110.

Arianita, L., Aznedra, \& Jaya Hendry. (2016). Sistem Akuntansi Penerimaan Kas; Studi Kasus pada Koperasi Karyawan PT. Epson Batam. Measuremen, 3(2), 98-113.

Arum, A. P., \& Nugroho, M. A. (2017). Perancangan Sistem Informasi Akuntansi Penerimaan Kas Berbasis Web pada Batik Pramanca. Nominal, Barometer Riset Akuntansi Dan Manajemen, 6(1), 27-49. https://doi.org/10.21831/nominal.v6i1.14331

Fathoni, A. (2018). Sistem Akuntansi Penerimaan Kas pada KJKS BMT Mandiri Sejahtera Karangcangkring Gresik Jawa Timur. Al-Idarah: Jurnal Manajemen Dan Administrasi Islam, 2(1), 137-146. https://doi.org/http://dx.doi.org/10.22373/alidarah.v2i1.3154

IAI. (2009). Standar Akuntansi Keuangan. Salemba Empat.

James, H. (2009). Accounting Information System (4th ed.). Salemba Empat.

Kristeria, Feranika, A., \& Gunardi. (2020). Perancangan Sistem Informasi Akuntansi Penerimaan dan Pengeluaran Kas Berbasis Web pada PT Pos Indonesia (Persero) Kota Jambi. Account, $7(2), \quad 1309-1320$. https://doi.org/https://doi.org/10.32722/acc.v7i2.3548

Mulyadi. (2018). Sistem Akuntansi (4th ed.). Salemba Empat.

Pradnyawati, I. G. A. A., Suwendra, I. W., \& Sujana, I. N. (2019). Analisis Sistem Akuntansi Penerimaan dan Pengeluaran Kas Pada Koperasi Pegawai Negeri Setya Graha di Kecamatan Mendoyo Tahun 2017. Jurnal Pendidikan Ekonomi Undiksha, 11(1), 249-259. https://doi.org/http://dx.doi.org/10.23887/jjpe.v11i1.20145 
Owner: Riset \& Jurnal Akuntansi

e-ISSN : 2548-9224 | p-ISSN : 2548-7507

Volume 6Nomor 1, Januari 2022

Rubhiyanti, R., \& Putri Pertiwi, S. (2020). Rancang Bangun Sistem Penjualan Tunai dan Penerimaan Kas Berbasis Multiuser. Jurnal Ilmiah Ekonomi Dan Bisnis, 13(2), 5866. http://journal.stekom.ac.id/index.php/e-bisnis $\square$ page58

Saifudin, \& Pri, F. A. (2017). Sistem Informasi Akuntansi Penerimaan dan Pengeluaran Kas dalam Meningkatkan Pengendalian Internal Atas Pendapatan pada RSUP Dr. Kariadi Semarang. Jurnal Riset Akutansi Keuangan, 2(2), 123-138. https://doi.org/http://dx.doi.org/10.31002/rak.v2i2.221

Sugiyono. (2018). Metode Penelitian Kualitatif. Alfabeta.

Wayan Esteria, N., Sabijono, H., Lambey, L., Akuntansi, J., Ekonomi, F., \& Bisnis, D. (2016). Analisis Sistem Akuntansi Penerimaan dan Pengeluaran Kas pada PT. Hasjrat Abadi Manado. Jurnal Berkala Ilmiah Efisiensi, 16(04), 1087-1097. https://ejournal.unsrat.ac.id/index.php/jbie/article/view/14197/13771

Yudowati, R. (2018). Perancangan Sistem Informasi Akuntansi Penjualan Tunai (Studi Kasus PT. Adijaya Komputer). Jupiter. https://ejournal.borobudur.ac.id/index.php/08/article/view/548

Zahro, S. F. (2019). Perancangan Sistem Akuntansi Penjualan UD. Galansa Graha Motor Mayang Jember. International Journal of Social Science and Business, 3(3), 215222. https://doi.org/http://dx.doi.org/10.23887/ijssb.v3i3.20999

Zamzami, F., Nusa, N. D., \& Faiz, I. A. (2021). Sistem Informasi Akuntansi. Gadjah Mada University Press. http://ugmpress.ugm.ac.id 